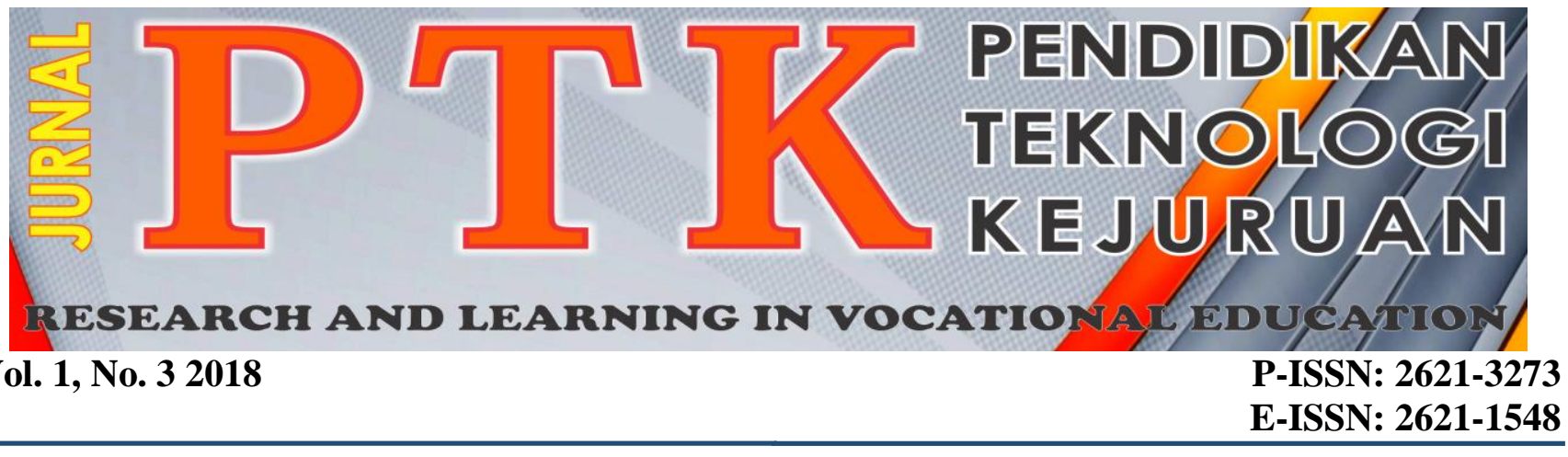

\title{
PEMANFAATAN LIMBAH ABU TERBANG BATUBARA (FLY ASH) DI PLTU OMBILIN SEBAGAI BAHAN KOAGULAN
}

\author{
Eka Rahmatul Aida ${ }^{1^{*}}$, Sri Yanti Lisha ${ }^{2}$ dan Yurike Puty ${ }^{3}$ \\ Teknik Lingkungan, Sekolah Tinggi Teknologi Industri (STTIND) Padang \\ ${ }^{*}$ Corresponding author, e-mail: yurikeputy@gmail.com ${ }^{1}$
}

\begin{abstract}
Abstrak - Energi listrik salah satunya dihasilkan dari energi kinetik uap yang menggunakan batubara sebagai bahan bakarnya. Penggunaan batubara menghasilkan hasil samping yaitu limbah abu dalam jumlah banyak yang berpotensi mencemari lingkungan apabila tidak ditangani dengan benar. Berbagai macam penelitian telah dilakukan untuk menangani limbah abu salah satunya yaitu menjadikan limbah abu menjadi bahan koagulan. Tujuan dari penelitian ini yaitu membuat bahan koagulan dengan cara mengekstrak abu terbang dengan menggunakan asam sulfat dengan variasi konsentrasi 1\%,2\%,3\%,4\%,5\%,10\%, dan 15\%. Pengujian kualitas koagulan fly ash ini dilakukan dengan cara dilakukan pengujian pada laboratorium dengan menguji nilai pH, turbidity, dan pengujian jar test guna melihat kualitas dari koagulan fly ash. Hasil dari pengujian laboratorium yaitu didapatkan koagulan pada konsentrasi $4 \%$ merupakan hasil terbaik yaitu didapatkan nilai pH 6,98, conductivity $221,8 \mu \mathrm{S} / \mathrm{cm}$, tubidity 3,50 NTU dari hasil tersebut menyatakan bahwa koagulan fly ash bisa digunakan sebagai bahan alternatif pengganti alum karena sifat yang dimiliki relatif sama dan dari uji jar test hasil pengujian sampel yang menggunakan koagulan fly ash mampu membuat sampel kedalam range standard kualitas air PLTU Ombilin. Karena menjadi bahan alternatif pengganti alum maka dengan menggunakan koagulan fly ash ini juga dapat menguntungkan secara materi.
\end{abstract}

\section{Kata kunci : limbah,fly ash,koagulan,bahan alternatif}

\begin{abstract}
Electrical energy, one of which is produced from the kinetic energy of steam that uses coal as fuel. The use of coal produces byproducts of ash waste in large quantities that potentially pollute the environment if not handled properly. Various studies have been done to handle ash waste one of them is to make ash waste into coagulant material. The purpose of this research is to make coagulant material by extracting fly ash by using sulfuric acid with concentration variations of 1\%, 2\%, 3\%, 4\%, 5\%, 10\%, and 15\%. Coagulant quality testing of fly ash is done by testing in the laboratory by testing the value of $\mathrm{pH}$, turbidity, and test jar test in order to see the quality of fly ash coagulant. The result of laboratory test that is got coagulant at $4 \%$ concentration is the best result that is got $\mathrm{pH}$ value 6,98 , conductivity $221,8 \mu \mathrm{S} / \mathrm{cm}$, tube of 3,50 NTU from result stated that coagulant fly ash can be used as alternative material of alum because the properties are relatively the same and from the test jar test the test results of samples using coagulant fly ash able to make the sample into the standard range water quality PLTU Ombilin. Because becoming alternative material of alum substitute hence by using coagulant fly ash this also can be profitable materially.
\end{abstract}

Keywords: waste, fly ash, coagulant, alternative materials

\section{Pendahuluan}

Manusia dan kebutuhan hidupnya tidak lepas dari sesuatu yang dinamakan energi. Salah satu kebutuhan manusia modern yang vital saat ini yakni kebutuhan akan energi listrik. Energi listrik yang dibutuhkan manusia bersumber dari berbagai macam energi kinetik, salah satunya yakni energi kinetik dari uap. Pembangkit yang mengandalkan energi kinetik dari uap untuk menghasilkan energi listrik disebut dengan Pembangkit Listrik Tenaga Uap (PLTU). Pembangkit listrik tenaga uap menggunakan berbagai macam bahan bakar terutama batubara. Proses pembakaran batubara terjadi dalam sistem boiler dimana selain 
menghasilkan uap, dalam sistem ini juga menimbulkan produk samping atau limbah.

Secara umum yang disebut limbah adalah bahan sisa yang dihasilkan dari suatu kegiatan dan proses produksi, baik pada skala rumah tangga, industri, pertambangan, dan sebagainya (https://id.scribd.com). Limbah hasil industri pembangkit listrik dinamakan fly ash (abu terbang) yang berjumlah sebesar $80 \%$ dan bottom ash (abu dasar) sebesar $20 \%$ dari total limbah abu setiap produksi.

Fly ash batubara adalah limbah industri yang dihasilkan dari pembakaran batubara dan terdiri dari partikel halus. Abu terbang pada masa kini dipandang sebagai limbah pembakaran batubara. Penanganan abu terbang masih terbatas pada penimbunan di lahan kosong/landfill. Hal ini berpotensi bahaya bagi lingkungan dan masyarakat sekitar seperti, logam-logam dalam abu terbang terekstrak dan terbawa ke perairan, abu terbang tertiup angin sehingga mengganggu pernafasan.

Sudut pandang terhadap abu terbang harus diubah karena abu terbang merupakan bahan baku potensial yang dapat digunakan sebagai bahan koagulan. Pengujian yang dilakukan di labor Tekmira Bandung telah mengeluarkan nilai bahwa abu terbang memiliki kandungan $\mathrm{Al}_{2} \mathrm{O}_{3}$ sebesar $19,49 \%$ (SNI 13-368-1994), sementara kandungan $\mathrm{Al}_{2} \mathrm{O}_{3}$ yang digunakan pada pengolahan air di PLTU hanya sebesar 17 - 18\% (Certificate Of Analysist PT IAI). Berdasarkan hal tersebut fly ash memiliki potensial yang besar untuk digunakan menjadi bahan koagulan dengan cara diekstrak ion aluminium dari aluminanya $\left(\mathrm{Al}_{2} \mathrm{O}_{3}\right)$. Proses ekstraksi ion aluminium dapat dilakukan dengan beberapa cara, salah satunya dengan metode ekstraksi padat-cair (leaching) abu terbang batubara PLTU Ombilin yang telah dikalsinasi. Pada proses ekstraksi padat cair terdapat bahan pelarut yang digunakan bertujuan untuk memisahkan zat yang bisa terlarut pada bahan padat. Bahan pelarut yang digunakan pada penelitian ini adalah Asam Sulfat $\left(\mathrm{H}_{2} \mathrm{SO}_{4}\right)$ dan bahan padatnya yaitu fly ash yang akan menghasilkan bahan koagulan yang akan menjadi bahan alternatif pengganti alum/tawas.

Beberapa penelitian yang telah dilakukan untuk pemanfaatan fly ash sebagai koagulan ini antara lain adalah Recovery Alumina $\left(\mathrm{Al}_{2} \mathrm{O}_{3}\right)$ dari Coal Fly Ash menjadi Polyaluminium Chloride (PAC) oleh Nining Lintan Edi Wahyuni Mahasiswa Politeknik Negeri Bandung , Adsorpsi Zat Warna Tekstil dengan Menggunakan Abu Terbang (fly ash) untuk Variasi Massa Adsorben dan Suhu Operasi dengan Menggunakan $\mathrm{HCl}$ (Asam Clorida) oleh Zahrul,dkk di Universitas Ahmad Dahlan Yogyakarta, Pembuatan Adsorben dari Fly Ash Hasil
Pembakaran Batubara untuk Mengadsorbsi Logam Besi (Fe) oleh Novia,dkk dari Universitas Sriwajaya Palembang.

Alum berbentuk bubuk, butiran, atau bongkahan, dengan rumus kimia $\mathrm{Al}_{2}\left(\mathrm{SO}_{4}\right)_{3} \cdot \mathrm{xH}_{2} \mathrm{O}$. Kekeruhan dalam air dapat dihilangkan melalui penambahan sejenis bahan kimia yang disebut koagulan. Pada umumnya bahan seperti Aluminium sulfat $\left[\mathrm{Al}_{2}\left(\mathrm{SO}_{4}\right)_{3 \cdot 18} \mathrm{H}_{2} \mathrm{O}\right]$ atau sering disebut alum atau tawas, fero sulfat, Poly Aluminium Chlorida (PAC) dan poli elektrolit organik dapat digunakan sebagai koagulan (Alearts\&Santika,1984).

Manfaat dari penelitian ini yaitu mendayagunakan fly ash yang merupakan limbah yang terbuang menjadi bahan yang memiliki nilai ekonomis. Dimana pada salah satu unit pengolahan listrik tenaga uap yaitu PLTU Ombilin dalam satu bulannya rata - rata menggunakan $8.800 \mathrm{~kg}$ $14.000 \mathrm{~kg}$ alum/tawas $17 \%$ dengan harga Rp. $5300 / \mathrm{kg}$, dari data di atas dapat kita hitung berapa nilai ekonomi yang dihasilkan jika fly ash ini menjadi bahan koagulan. Sehingga dengan adanya penelitian ini kita akan mengetahui seberapa baik koagulan ini menurunkan nilai Turbidity dan diharapkan dapat mengurangi dampak negatif yang dihasilkan oleh industri yang menggunakan batubara sebagai sumber energinya, maka dari itu dilakukan penelitian tentang Pemanfaatan Limbah Abu Terbang Batubara (Fly Ash) di PLTU Ombilin sebagai Bahan Koagulan".

\section{METODE}

\section{Populasi Dan Sampel}

Populasi pada penelitian ini adalah koagulan dari limbah abu terbang batubara (fly ash) di PLTU Ombilin pada umumnya, sedangkan untuk sampel pada penelitian ini adalah koagulan dari limbah abu terbang batubara (fly ash) dengan diekstraksi menggunakan Asam Sulfat dengan konsentrasi berbeda.

\section{Variabel Penelitian}

Adapun penelitian memiliki batasan variabel penelitian supaya penelitian ini terarah yakni; penentuan nilai $\mathrm{pH}$, nilai turbidity dan Nilai Kandungan $\mathrm{Al}^{+3}$

\section{Alat Dan Bahan}

\section{Alat}

Alat yang digunakanpada penelitian ini meliputi : furnace, ayakan (screen) ukuran 200 mesh,mortar,cawan nikel, erlenmeyer $250 \mathrm{ml}$, pengaduk magnet (magnetic stirer), pipet volume Pyrex ukuran 1 dan 0,5 mL, labu ukur Pyrex ukuran $100 \mathrm{~mL}$,beaker glass Pyrex ukuran $100 \mathrm{~mL}$,beaker glass ukuran $500 \mathrm{~mL}$, gelas ukur Pyrex ukuran 50 $\mathrm{mL}$, corong, gunting, spatula, batang pengaduk gelas, derigen, neraca analitik OHAUS,Phipps \& 
Birds Stirrer,hot plate stirrer SB 162-3,HACH 2100Q Turbidity Meter,HANNA HI 8424 ,pH Meter,HANNA HI 8633 Conductivity Meter,HACH DR/890 Colorimeter, plastik, karet, kertas saring Whatman 41

\section{Bahan}

Bahan - bahan yang digunakan pada penelitian ini meliputi : Abu terbang dari PLTU Ombilin, Air sungai Batang Ombilin, $\mathrm{H}_{2} \mathrm{SO}_{4} 1 \%$, $\mathrm{H}_{2} \mathrm{SO}_{4} 2 \%, \mathrm{H}_{2} \mathrm{SO}_{4} 3 \%, \mathrm{H}_{2} \mathrm{SO}_{4} 4 \%, \mathrm{H}_{2} \mathrm{SO}_{4} 5 \%$, $\mathrm{H}_{2} \mathrm{SO}_{4} 10 \%, \mathrm{H}_{2} \mathrm{SO}_{4} 15 \%, \mathrm{H}_{2} \mathrm{SO}_{4} 98 \%$, Air demin, Poly Elektrolit.

\section{Prosedur Kerja}

\section{Pembuatan Larutan $\mathrm{H}_{2} \mathrm{SO}_{4}$}

Larutan $\mathrm{H}_{2} \mathrm{SO}_{4}$ yang akan diencerkan memiliki konsentrasi 98\%, Berat jenis dari $\mathrm{H}_{2} \mathrm{SO}_{4}$ adalah $1,84 \mathrm{~g} / \mathrm{ml}$ dan Berat Molekulnya adalah 98,08 $\mathrm{g} / \mathrm{mol}$. Langkah pertama yang dilakukan adalah mencari nilai Molaritas $\mathrm{H}_{2} \mathrm{SO}_{4} 98 \%$, dimana Molaritas merupakan konsentrasi larutan yang menyatakan jumlah mol zat terlarut dalam 1 liter larutan dengan penetapan rumus kimia zat Molaritas. Molaritas $\mathrm{H}_{2} \mathrm{SO}_{4} 98 \%$ dinyatakan dengan M1 rumusnya yaitu:

$$
\mathrm{M}=(10 \times \% \times \mathrm{bj}) / \mathrm{BM}
$$

$$
\begin{aligned}
\text { Contoh perhitungan } \mathrm{M} 1\left(\mathrm{H}_{2} \mathrm{SO}_{4} 98 \%\right), \\
\begin{aligned}
\mathrm{M} & =(10 \mathrm{x} \% \mathrm{xbj}) / \mathrm{BM} \\
& =(10 \times 98 \% \times 1,84 \mathrm{~g} / \mathrm{ml}) / 98,08 \mathrm{~g} / \mathrm{mol} \\
& =18,38 \mathrm{M}
\end{aligned}
\end{aligned}
$$

Langkah kedua yang dilakukan adalah mencari nilai Molaritas $\mathrm{H}_{2} \mathrm{SO}_{4}$ yang diencerkan (M2) dengan rumus :

$$
\begin{aligned}
& \mathrm{M}=(1 \mathrm{O} \times \% \times \mathrm{bj}) / \mathrm{BM} \\
& \text { Contoh perhitungan } \mathrm{M} 2\left(\mathrm{H}_{2} \mathrm{SO}_{4} 1 \%\right), \\
& \mathrm{M}=(10 \times \% \times b j) / \mathrm{BM} \\
&=(10 \times 1 \% \times 1,84 \mathrm{~g} / \mathrm{ml}) / 98,08 \mathrm{~g} / \mathrm{mol} \\
&=0,19 \mathrm{M}
\end{aligned}
$$

Perhitungan pembuatan larutan $\mathrm{H}_{2} \mathrm{SO}_{4}$ yang diencerkan menggunakan rumus pengenceran Molaritas, yaitu

$$
\mathrm{M} 1 \mathrm{xV} 1=\mathrm{M} 2 \mathrm{xV} 2
$$

Dengan diketahui, $\mathrm{M} 1=18,38 \mathrm{M}, \mathrm{M} 2=0,19 \mathrm{M}$ $, \mathrm{V} 1=\ldots ?, \mathrm{~V} 2=100 \mathrm{~mL}$

$$
\begin{aligned}
& \mathrm{M} 1 \times \mathrm{V} 1=\mathrm{M} 2 \times \mathrm{x} 2 \\
& 18,38 \mathrm{M} \times \mathrm{V} 1=0,19 \mathrm{M} \times 100 \mathrm{~mL} \\
& \begin{aligned}
& 18,38 \mathrm{M} \times \mathrm{V} 1=19 \mathrm{M} \mathrm{mL} \\
& \mathrm{V} 1=19 \mathrm{M} \mathrm{mL} / 18,38 \mathrm{M} \\
&=1,03 \mathrm{~mL}
\end{aligned}
\end{aligned}
$$

Gunakan rumus yang sama untuk pengenceran 2 $\%, 3 \&, 4 \%, 5 \%, 10 \%$, dan $15 \%$, dengan cara kerja pembuatan larutan yang dilakukan adalah sebagai berikut :

1. Pembuatan Larutan $\mathrm{H}_{2} \mathrm{SO}_{4} \quad 1 \%$

Pembuatan larutan $\mathrm{H}_{2} \mathrm{SO}_{4} \quad 1 \%$ dilakukan dengan mengencerkan $1,03 \mathrm{ml} \mathrm{H}_{2} \mathrm{SO}_{4} \quad 98 \%$ dalam labu ukur $100 \mathrm{~mL}$ dengan air demin hingga tanda batas.

2. Pembuatan Larutan $\mathrm{H}_{2} \mathrm{SO}_{4} \quad 2 \%$

Pembuatan larutan $\mathrm{H}_{2} \mathrm{SO}_{4} \quad 2 \%$ dilakukan dengan mengencerkan 2,06 $\mathrm{ml} \mathrm{H}_{2} \mathrm{SO}_{4} \quad 98 \%$ dalam labu ukur $100 \mathrm{~mL}$ dengan air demin hingga tanda batas.

3. Pembuatan Larutan $\mathrm{H}_{2} \mathrm{SO}_{4} \quad 3 \%$

Pembuatan larutan $\mathrm{H}_{2} \mathrm{SO}_{4} \quad 3 \%$ dilakukan dengan mengencerkan $3,09 \mathrm{ml} \mathrm{H}_{2} \mathrm{SO}_{4} 98 \%$ dalam labu ukur $100 \mathrm{~mL}$ dengan air demin hingga tanda batas.

4. Pembuatan Larutan $\mathrm{H}_{2} \mathrm{SO}_{4} 4 \%$

Pembuatan larutan $\mathrm{H}_{2} \mathrm{SO}_{4} \quad 4 \%$ dilakukan dengan mengencerkan $4,12 \mathrm{ml} \mathrm{H}_{2} \mathrm{SO}_{4} \quad 98 \%$ dalam labu ukur $100 \mathrm{~mL}$ dengan air demin hingga tanda batas.

5. Pembuatan Larutan $\mathrm{H}_{2} \mathrm{SO}_{4} 5 \%$

Pembuatan larutan $\mathrm{H}_{2} \mathrm{SO}_{4} \quad 5 \%$ dilakukan dengan mengencerkan 5,15 $\mathrm{ml} \mathrm{H}_{2} \mathrm{SO}_{4} \quad 98 \%$ dalam labu ukur $100 \mathrm{~mL}$ dengan air demin hingga tanda batas.

6. Pembuatan Larutan $\mathrm{H}_{2} \mathrm{SO}_{4} \quad 10 \%$

Pembuatan larutan $\mathrm{H}_{2} \mathrm{SO}_{4} 10 \%$ dilakukan dengan mengencerkan $10,3 \mathrm{ml} \mathrm{H}_{2} \mathrm{SO}_{4} \quad 98 \%$ dalam labu ukur $100 \mathrm{~mL}$ dengan air demin hingga tanda batas.

7. Pembuatan Larutan $\mathrm{H}_{2} \mathrm{SO}_{4} \quad 15 \%$

Pembuatan larutan $\mathrm{H}_{2} \mathrm{SO}_{4} 15 \%$ dilakukan dengan mengencerkan $15,45 \mathrm{ml} \mathrm{H}_{2} \mathrm{SO}_{4} \quad 98 \%$ dalam labu ukur $100 \mathrm{~mL}$ dengan air demin hingga tanda batas.

\section{Pembuatan Larutan Poly Elektrolit 0,1\%}

1. Ditimbang Poly Elektrolit ${ }_{(s)}$ sebanyak $0,1 \mathrm{~g}$ dan dimasukkan kedalam beaker glass $100 \mathrm{ml}$.

2. Ditambahkan air demin $100 \mathrm{ml}$.

3. Dimasukkan pengaduk magnet (magnetic stirer) kedalam beaker glass dan di stirer selama 30 menit.

4. Didiamkan.

\section{Penurunan Kadar Air dalam Abu Terbang}

Perlakuan awal adalah mengeringkan abu terbang dari PLTU Ombilin dengan cara dioven hingga berat abu terbang konstan pada suhu 40-45 ${ }^{0} \mathrm{C}$ selama 24 jam, kemudian dilakukan penggerusan dengan mortar dan pengayakan dengan screen hingga lolos 200 mesh. 


\section{Proses Kalsinasi}

Proses kalsinasi dilakukan dengan memanaskan abu terbang kering yang lolos 200 mesh tersebut ke dalam furnace pada suhu $820{ }^{\circ} \mathrm{C}$ selama 2 jam.

\section{Proses Ekstraksi Padat-Cair}

Proses ekstraksi dilakukan dengan melarutkan 10 gram sampel abu terbang kering 200 mesh yang telah dikalsinasi ke dalam larutan asam sulfat $1 \%$, asam sulfat $2 \%$, asam sulfat $3 \%$, asam sulfat $4 \%$, asam sulfat $5 \%$, asam sulfat $10 \%$, dan asam sulfat $15 \%$ sebanyak $100 \mathrm{~mL}$. Dilakukan pengadukan dan pemanasan pada suhu $95{ }^{\circ} \mathrm{C}$ selama 5 jam dengan menggunakan stirrer. Setelah itu, dilakukan penyaringan dengan menggunakan kertas saring whatman 41 untuk memisahkan bahanbahan yang larut. Sehingga hasil penyaringan akan diperoleh 7 jenis Filtrat yaitu: larutan abu 1\%, larutan abu 2\%, larutan abu 3\%, larutan abu 4\%, larutan abu $5 \%$, larutan abu $10 \%$, dan larutan abu $15 \%$.

\section{Proses Pengujian Jar Test}

Pengujian dengan larutan Poly Elektrolit 0,1\%

1. Dimasukkan Air sungai PLTU Ombilin kedalam 5 beaker glass $500 \mathrm{~mL}$.

2. Diukur $\mathrm{pH}$, Conduktivity, dan Turbidity untuk data awalnya.

3. Dilakukan pengadukan dengan alat PHIPPS \& BIRD STIRRER dengan mengatur kecepatan maksimal $250 \mathrm{rpm}$ dan minimalnya $64 \mathrm{rpm}$.

4. Diukur Larutan abu $1 \%$ sebanyak $0,1 \mathrm{ml} ; 0,2 \mathrm{ml}$ ; $0,3 \mathrm{ml} ; 0,4 \mathrm{ml} ; 0,5 \mathrm{ml} ; 0,6 \mathrm{ml}$; dan $0,7 \mathrm{ml}$ dengan menggunakan pipet volume kemudian dimasukkan kedalam beaker glass.

5. Diaduk dengan alat PHIPPS \& BIRD STIRRER dengan kecepatan maksimal $250 \mathrm{rpm}$ selama 3 menit.

6. Ditambahkan $0,5 \mathrm{ml}$ Larutan Poly Elektrolit $0,1 \%$ kedalam masing-masing beaker glass dan diaduk dengan kecepatan 64 rpm selama 5 menit.

7. Didiamkan selama 15 menit

8. Kemudian ukur $\mathrm{pH}$, Conduktivity, dan Tubidity pada masing-masing beaker glass.

9. Dilakukan pengujian yang sama untuk larutan abu $2 \%$, larutan abu 3\%, larutan abu 4\%, larutan abu 5\%, larutan abu 10\% dan larutan abu $15 \%$.

\section{Proses Pengujian Kualitas Koagulan}

A. Proses Pengujian nilai pH (Hanna Manual book)

1. Cuci Elektroda dengan air demineral

2. Celupkan elektoda dengan sampel

3. Tekan pust bottom pH METER (On)

4. Temperatur pengecekan sesuai dengan temperature ruang $\left( \pm 25^{\circ} \mathrm{C}\right)$

5. Catat hasil pengukuran

6. Matikan alat sesudah dipakai
B. Proses Pengujian nilai Conductivity (Hanna Manual book)

1. Cuci elektroda dengan air demineral

2. Celupkan elektroda ke dalam sampel

3. Tekan pust bottom Conductivity Meter (On)

4. Temperatur pengecekan sesuai dengan temperatur ruang $\left( \pm 25^{\circ} \mathrm{C}\right)$

5. Catat hasil pengukuran

6. Matikan alat sesudah dipakai

C. Proses Pengujian nilai Turbidity (Hach 2100 Q, Manual Book)

1. Isikan sampel ke dalam cell hingga tanda batas $(10 \mathrm{~mL})$

2. Usap cell menggunakan tisu yang bersih untuk menghilangkan noda air / bekas sidik jari

3. Tekan tombol On untuk menghidupkan alat Turbidity Meter

4. Masukkan cell sampel ke dalam ruang cell dengan mengorientasikan tanda garis pada bagian depan ruang cell.

5. Tekan tombol Read, kemudian angka turbiditas akan muncul (dalam NTU)

6. Catat hasil pengukuran

7. Matikan alat sesudah dipakai

D. Pengujian kandungan ion $\mathrm{Al}^{+3}$

Pengujian kandungan ion $\mathrm{Al}^{+3}$ dengan

menggunakan alat HACH DR/890 Colorimeter. Untuk pengujian kandungan ion $\mathrm{Al}^{+3}$ pada masing-

masing larutan abu $1 \%$, larutan abu $2 \%$, larutan abu $3 \%$, larutan abu $4 \%$ larutan abu 5\%, larutan abu $10 \%$, dan larutan abu $15 \%$. Dimasukkan larutan abu $1 \%$, larutan abu $2 \%$, larutan abu $3 \%$, larutan abu $4 \%$, larutan abu $5 \%$, larutan abu $10 \%$, dan larutan abu $15 \%$ masing-masingnya sebanyak $50 \mathrm{~mL}$ kedalam gelas ukur, Ditambahkan Asam askorbat, reagent aluminium sambil diaduk dengan batang pengaduk kaca kemudian didiamkan selama 3 menit, setelah 3 menit masukkan $25 \mathrm{~mL}$ kedalam tube (1) $25 \mathrm{~mL}$ untuk sampel, $25 \mathrm{~mL}$ lagi yang terdapat pada gelas ukur ditambahkan reagent bleaching dan didiamkan selama 30 detik. Lalu masukkan kedalam tube (2) 25 $\mathrm{mL}$ untuk blanko kemudian didiamkan selama 15 menit setelah itu masukkan tube (2) kedalam alat HACH DR/890 Colorimeter lalu tekan Zero, ganti tube (2) dengan tube (1) masukkan kedalam alat HACH DR/890 Colorimeter kemudian tekan Read maka akan muncul hasilnya. 


\section{HASIL DAN PEMBAHASAN}

Hasil

1. Produk Hasil

Produk pemanfaatan limbah abu terbang batubara ini memiliki bentuk cair , berwarna bening kekuningan, bersifat asam apabila berekasi dengan air.
2. Hasil Uji

Dari hasil uji laboratorium yang dilakukan secara triplodi Laboratorium PT PLN (Persero) Sektor Pembangkitan dan Pengendalian Pembangkitan Ombilin maka diperoleh data rata - rata sebagai berikut:

Tabel.1 Hasil Uji Kandungan Abu Terbang

\begin{tabular}{|c|c|c|c|c|}
\hline \multicolumn{5}{|c|}{$\begin{array}{c}\text { HASIL UJI LABORATORIUM TERHADAP } \\
\text { KANDUNGAN ABU TERBANG PLTU OMBILIN } 2017\end{array}$} \\
\hline NO & $\begin{array}{l}\text { NAMA } \\
\text { ANALIS } \\
\end{array}$ & $\begin{array}{l}\text { VOLUME } \\
\text { FILTRAT (mL) }\end{array}$ & $\begin{array}{l}{\left[\mathrm{H}_{2} \mathrm{SO}_{4}\right]} \\
(\%)\end{array}$ & $\begin{array}{l}\text { KANDUNGAN ALUMINA } \\
\text { FLY ASH (ppm) }\end{array}$ \\
\hline 1 & \multirow{7}{*}{$\begin{array}{l}\text { YURIKE } \\
\text { PUTY }\end{array}$} & 90 & $1 \%$ & 1.035 \\
\hline 2 & & 89 & $2 \%$ & 1.014 \\
\hline 3 & & 90 & $3 \%$ & 2.200 \\
\hline 4 & & 90 & $4 \%$ & 3.755 \\
\hline 5 & & 89 & $5 \%$ & 1.231 \\
\hline 6 & & 89 & $10 \%$ & 1.076 \\
\hline 7 & & 90 & $15 \%$ & 1.175 \\
\hline
\end{tabular}

\section{Pembahasan}

Dari hasil pengujian kandungan ion $\mathrm{Al}^{+3}$ yang dilakukan secara triplo diperoleh hasil kandungan $\operatorname{ion}^{\mathrm{Al}^{+3}}$ yang tertinggi yaitu dengan menggunakan larutan abu $4 \%$ yaitu dengan nilai 3.755 ppm.

Dari hasil Jar Test yang dilakukan pada air sungai PLTU Ombilin diperoleh data yang terbaik yaitu dengan menggunakan $0,5 \mathrm{~mL}$ larutan abu $4 \%$ dan dengan penginjeksian $0,5 \mathrm{ml}$ larutan poly elektrolit $0,1 \%$. Sehingga diperoleh turbiditas 3,50 NTU, conduktivity $221,8 \mu \mathrm{S} / \mathrm{cm}$, dan $\mathrm{pH}$ 6,98.

Pada penelitian ini nilai $\mathrm{pH}$ yang didapatkan semuanya turun dari $\mathrm{pH}$ sebelum pengujian jar test, baik pada konsentrasi $1 \%$ hingga konsentrasi $15 \%$, namun $\mathrm{pH}$ terburuk mulai tampak pada konsentrasi $10 \%$ dan $15 \%$ dimana nilai $\mathrm{pH}$ yang didapatkan jauh dibawah 6. Sementara pada konsentrasi $1 \%$ $5 \%$ nilai $\mathrm{pH}$ yang didapatkan sesuai dengan batasan nilai $\mathrm{pH}$. Ini membuktikan bahwa produk koagulan yang dihasilkan bekerja dalam Efektifitas nilai $\mathrm{pH}$ terhadap pengaruh konsentrasi asam sulfat dengan volume koagulan $0,5 \mathrm{~mL}$ dan $0,5 \mathrm{~mL}$ poly $0,1 \%$.
Pengujian nilai konduktifitas pada penelitian ini menunjukkan nilai konduktifitas setelah penginjeksian produk koagulan mengalami peningkatan dari nilai sebelum penginjeksian hal ini dikarenakan adanya penambahan mineral $\mathrm{Al}^{+3}$, dimana berbanding terbalik dengan nilai $\mathrm{pH}$ yang mengalami penurunan. Pada koagulan konsentrasi 1$5 \%$ kecuali $5 \%$ dengan volume ekstrak $0,7 \mathrm{~mL}$ masuk dalam batasan standar konduktifitas yang ditentukan oleh PLTU Ombilin yaitu <250 $\mu \mathrm{mhos} / \mathrm{cm}$. Sementara untuk konsentrasi $10 \%$ hanya volume ekstrak 0,1 dan $0,2 \mathrm{~mL}$ yang masuk dalam batasan standar yang ditetapkan dan $15 \%$ hanya volume ekstrak $0,1 \mathrm{~mL}$ yang masuk dalam batasan standar, selain dari itu nilai konduktifitasnya melewati batasan standard yang ditetapkan.

. Pada penambahan $0,3 \mathrm{~mL}$ dan $0,4 \mathrm{~mL}$ koagulan terjadi penggumpalan yang mulai baik dan setelah ditambahkan flokulan flok flok yang terbentuk semakin besar dan mudah mengendap secara kasat mata, tetapi setelah dilakukan pengujian nilai turbidity nya masih berada diatas standar dan dilihat masih ada padatan yang berukuran yang sangat kecil 
tak kasat mata yang membuat nilai turbiditynya diatas standar. Pada penambahan 0,5 mL, 0,6 mL dan $0,7 \mathrm{~mL}$ koagulan pada salah satu konsentrasi didapatkan nilai turbiditynyadibawah standard yang ditetapkan oleh PLTU Ombilin yaitu <5 NTU. Nilai turbidity yang didapatkan pada penambahan $0,5 \mathrm{~mL}$ koagulan konsentrasi $4 \%$ dan $0,5 \mathrm{~mL}$ flokulan yaitu 3,50 NTU, penambahan $0,6 \mathrm{~mL}$ koagulan konsentrasi $4 \%$ dan $0,5 \mathrm{~mL}$ flokulan didapatkan nilai 4,17 NTU dan penambahan $0,7 \mathrm{~mL}$ koagulan konsentrasi $4 \%$ dan $0,5 \mathrm{~mL}$ flokulan didapatkan nilai turbiditynya 4,93 NTU. Tiga variasi volume koagulan ini merupakan volume tepat yang didapatkan dari pengujian jar test yang dilakukan karena sesuai dengan standar yang ditetapkan oleh PLTU Ombilin. Penurunan nilai turbidity secara drastis terjadi pada uji jar test pertama pada penambahan $0,5 \mathrm{~mL}$ kaogulan konsentrasi $5 \%$ dan $0,5 \mathrm{~mL}$ flokulan dimana nilai turbidity air sampel sebelum uji jar test yaitu 402 NTU setelah pengujian menjadi 14,0 NTU namun nilai turbidity ini masih berada jauh diatas standar PLTU Ombilin tetapi membuktikan kinerja produk pemanfaatan limbah abu terbang batubara ini bisa dijadikan sebagai bahan koagulan karena dapat menjadikan air yang sangat keruh menjadi air air yang jernih dan menurunkan secara drastis nilai turbidity yang tinggi menjadi rendah.

Pemanfaatan Limbah abu terbang batubara ini selain memberikan dampak positif terhadap lingkungan juga dapat dimanfaatkan sebagai bahan koagulan yang bernilai ekonomi, karena dengan pemanfaatan limbah abu terbang batubara akan digunakan sebagai bahan alternatif alum / tawas di PLTU Ombilin.

Pemanfaatan limbah abu terbang batubara di PLTU Ombilin berdasarkan uji jar test mendapatkan hasil terbaik pada produk koagulan $4 \%$, yang berarti konsentrasi tepatnya yaitu asam sulfat $4 \%$. Sehingga nilai ekonomi dapat dihitung berdasarkan keuntungan yang diperoleh dari penggunaan koagulan fly ash dibandingkan dengan penggunaan alum di pasaran. Dari rencana anggaran biaya yang telah dihitung dapat dilihat bahwa apabila kita memproduksi dan menjual koagulan fly ash di pasaran maka akan menguntungkan bagi produsen dan bahkan disaat harga jual yang kita berikan lebih rendah dibandingkan dengan harga koagulan yang telah ada di pasaran.

\section{KESIMPULAN}

Pada penelitian yang dilakukan terhadap pemanfaatan limbah abu terbang batubara sebagai bahan koagulan didapatkan hasil sebagai berikut :
1. Fly ash dapat digunakan sebagai koagulan karena memiliki kemampuan untuk menjadikan partikel koloid tidak stabil sehingga partikel siap membentuk flok (gabungan partikel-partikel kecil), yang dibuktikan dengan turunnya nilai turbidity air sampel dalam uji jar test.

2. Konsentrasi kandungan abu tertinggi hasil dari ekstraksi tertinggi ditunjukkan oleh hasil ekstraksi abu terbang batubara menggunakan larutan abu 4\% dengan nilai aluminium 3.760 ppm.

3. Komposisi yang tepat dari koagulan fly ash dapat menjernihkan air yaitu diinjeksikan sebanyak 0,5 $\mathrm{mL}$ koagulan fly ash dengan konsentrasi 4\%, komposisi didapatkan dari uji jar test yang dilakukan pada laboratorium.

4. Nilai ekonomi yang didapatkan yaitu senilai Rp. 1.692.500 untuk produksi pembuatan 5340 Liter koagulan fly ashyang diperoleh pada bulan ke 5 .

\section{DAftar Pustaka}

[1] A.K Haghi, 2011. "Sumber Limbah". Nova Science. Canada

[2] Aleart dan Santika, 1984. "Poly Aluminium Cloryte sebagai Koagulan”.Penerbit Usaha Nasional. Surabaya

[3] Al-Zahrani, A.A. dan Muhammad, H.A. 2009. Extraction of Alumina from Local Clays by Hidrochloric Acid Process. JKAU: Eng. Sci. Vol. 20 (2): 29-41.

[4] Anonim. 2013. Analisa Jar Test dalam Air. Dalam http://goelanzsaw.blogspot.com/2013/02/jart-test/ diakses pada Kamis 6 April 2017 pukul 15.05 WIB.

[5] Anonim 2. 2014. Proses Pengolahan Air dengan Metoda Koagulasi dan Filtrasi. Dalam http://ardra.biz/sain-teknologi/ilmu-danteknologiterapan/pengolahan-air-limbah-carakimia-koagulasi/ diakses pada Kamis 6 April 2017 pukul 15.12 WIB.

[6] Anonim 3. 2008. Bahan Kimia Penjernih Air (Koagulan). Dalam https://smk3ae.wordpress.com/2008/08/05/bahankimia-penjernih-air-koagulan/smk3 Kimia Madiun diakses pada Senin 10 April 2017 pukul 10.40 WIB

[7] Aptika. 2010. Penggunaan Abu Terbang (Fly Ash) dari Limbah Padat Tebu Sebagai AlternatifPerekatpadaPolimer.

[8] Dafi,A. 2009. "Sifat Fly Ash". Jurnal Teknologi Mineral dan Batubara

[9] Gunadarma. 2010. Air Bersih. Dalam http://elearning.gunadarma.ac.id/docmodul/rekaya sa_lingkungan/bab2_sistem_penyEdian_air_bersih 
.pdf diakses pada Senin 10 April 2017 pukul 10.55 WIB

[10] Ign Suharto. 2011. “ Pengertian Limbah”. CV. Andi Offset. Yogyakarta

[11] Jenie. 1993. "Jenis - Jenis Koagulan". Kanisius. Jakarta

[12] Juju, 2012. Parameter Fisika Kimia Biologi Penentu Kualitas Air. Dalam https://jujubandung.wordpress.com/2012/06/08/par ameter-fisika-kimia-biologi-penentu-kualitas-air-2/ diakses pada Senin 22 Mei 2017 pukul 10.40 WIB

[13] Kusnaedi. 2010. "Koagulasi”. Penebar Swadaya. Bekasi

[14] Mannual Book of ASTM. 1987. Standards Water and Environmental Technology. vol. 11. 01: 1916. Race Street Philadelphia. Philadelphia.

[15] Manurung. 2012. "Faktor Koagulasi dan Flokulasi”. Reksadana Investasiku. Jakarta

[16] Nehari, S. 1997. Process Recovery of Alumina and Silika. United State Patent : USA No.WO 97 22554.

[17] Retno,S., Winda, A. P. 2010. Studi Pengambilan Kembali Alumina dari Limbah Padat Lumpur
Perusahaan Daerah Air Minum (PDAM) Intan Banjar. Banjarbaru : Fakultas Teknik, Universitas Lambung Mangkurat.

[18] Said, Nusa Idaman. 2011. "Penggolongan Limbah Domestik". BPPT. Jakarta

[19] Sukandarrumidi,. 1995. Batubara dan Gambut. Gadjah Mada University Press. Yogyakarta.

[20] Sukandarrumidi,. 2005. Batubara dan Pemanfaatannya. Pengantar Teknologi Batubara Menuju Lingkungan Bersih. Gadjah Mada University Press Yogyakarta.

[21] Yurike ,Puty. 2011. Laporan Prakerin Analisis Kualitas Pada Sistem Air Internal di PLTU Ombilin. SMTI Padang.

[22] Zumaro, A. R., \& Arbi, Y. (2017). Perancangan Reaktor Biogas Di Uptd Pasar Ternak Palangki. Padang: Jurnal sains dan Teknologi sttind padang. Retrieved from http://ojs.sttind.ac.id/ojs/index.php/Sain/articl e/view/61 